\title{
Life and death of Vladimir Mikhailovich Bekhterev
}

\author{
Vida e morte de Vladimir Mikhailovich Bekhterev \\ Péricles Maranhão-Filho', Eliana Teixeira Maranhão ${ }^{2,3}$, Eliasz Engelhardt4
}

\begin{abstract}
Vladimir Mikhailovich Bekhterev was a Russian innovative neuroscientist, extraordinary in the study, diagnosis, and research in the fields of neurology, psychology, morphology, physiology, and psychiatry. Considering the ample and multifaceted scientific feats, only some are touched in a very brief manner. However, it is necessary to highlight his contributions to neurology, with the description of structures, signs and syndromes, to physiology, including reflexology, which later underpinned behaviorism, to psychology, including objective psychology and suggestion. His accomplishments and legacy remained until the present days. Some comments about the scenery that involved his death are also presented.
\end{abstract}

Keywords: Bekhterev, neurology, reflexology, psychology, suggestion.

\section{RESUMO}

Vladimir Mikhailovich Bekhterev foi um neurocientista russo inovador, extraordinário no estudo, diagnóstico, e pesquisa nas áreas da neurologia, psicologia, morfologia, fisiologia e psiquiatria. Considerando seus feitos científicos amplos e multifacetados, apenas alguns são tocados de um modo muito abreviado. Entretanto, é necessário realçar suas contribuições à neurologia, com a descrição de estruturas, sinais e síndromes, à fisiologia, compreendendo a reflexologia, que mais tarde fundamentou o behaviorismo, à psicologia, incluindo a psicologia objetiva e a sugestão. Suas realizações e legado se mantiveram até a presente data. Alguns comentários sobre o cenário que envolveu sua morte também são apresentados.

Palavras-chave: Bekhterev, neurologia, reflexologia, psicologia, sugestão.

Vladimir Mikhailovich Bekhterev (or Bechterew, or von Bechterew) (1857-1927), was an extraordinary neurologist, and exceled also in the fields of psychiatry, psychology, morphology, physiology, and pioneered the studies of mental illness in Russia ${ }^{1,2}$. Some of his very ample and multifaceted scientific contributions will be touched in a very brief manner.

\section{THE MAN - FIRST STEPS}

Bekhterev was born in a small village in the Ural Mountains, from Mikhail Petrovichew, a police officer, and Maria Mikhailovna, an educated woman ${ }^{1,2,3}$. Completing the gymnasium he was accepted into the St. Petersburg's Military Medical Academy ${ }^{4}$, graduating at age 21. He got his habilitation with the Doctor thesis, presented in 1881, "The experience of clinical investigation of the body temperature in some forms of mental diseases" ${ }^{\prime 1,2,3}$.

Bekhterev was a modest and undemanding man that disliked social life. In 1879 he married Natalya Bazilevskaya, who proved to be an excellent housewife and great companion, and they had six children. His figure impressed by the large head, the face framed by a large beard, sharp black eyes under bushy eyebrows ${ }^{1,4}$ (Figure 1). He showed a bright and inquisitive mind, unwavering persistence to achieve his goals, and an enormous capacity for work. Often, in the intervals of his lectures, rather than rest, he led hypnosis sessions in the auditorium (Figure 2). He needed only a few hours of sleep, and in the morning, still in bed, he was already working on his manuscripts ${ }^{2,3}$.

\footnotetext{
1 Universidade Federal do Rio de Janeiro, Faculdade de Medicina, Hospital Universitário Clementino Fraga Filho, Serviço de Neurologia, Rio de Janeiro RJ, Brazil; 2Instituto Nacional de Câncer, Serviço de Fisioterapia, Rio de Janeiro RJ, Brazil;

${ }^{3}$ American Physical Therapy Association for Vestibular Rehabilitation Certified, Alexandria VA, USA;

${ }^{4}$ Universidade Federal do Rio de Janeiro, Unidade de Neurologia Cognitiva e do Comportamento, Instituto de Neurologia Deolindo Couto/Instituto de Psiquiatria-CDA-IPUB, Rio de Janeiro RJ, Brazil.

Correspondence: Péricles Maranhão Filho;Av. Prefeito Dulcídio Cardoso 1680/1802; 22620-311 Rio de Janeiro RJ, Brasil; E-mail: pmaranhaofilho@gmail.com Conflict of interest: There is no conflict of interest to declare.
}

Received 27 May 2015; Accepted 17 June 2015. 


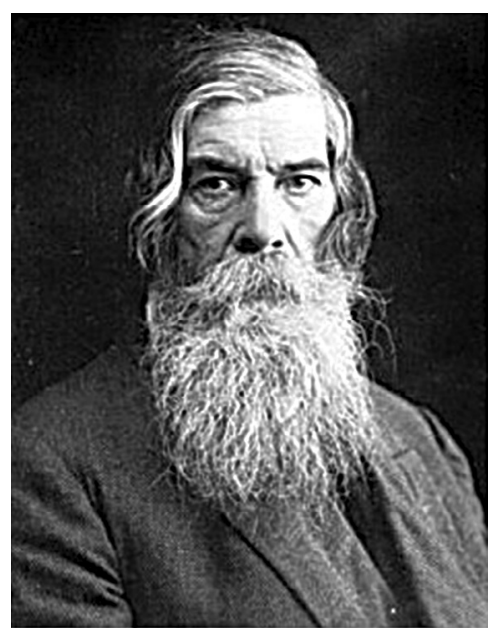

Access: http://www.iitvidya.com/tag/vladimir-bekhterev/

Figure 1. Vladimir Mikhailovich Bekhterev.

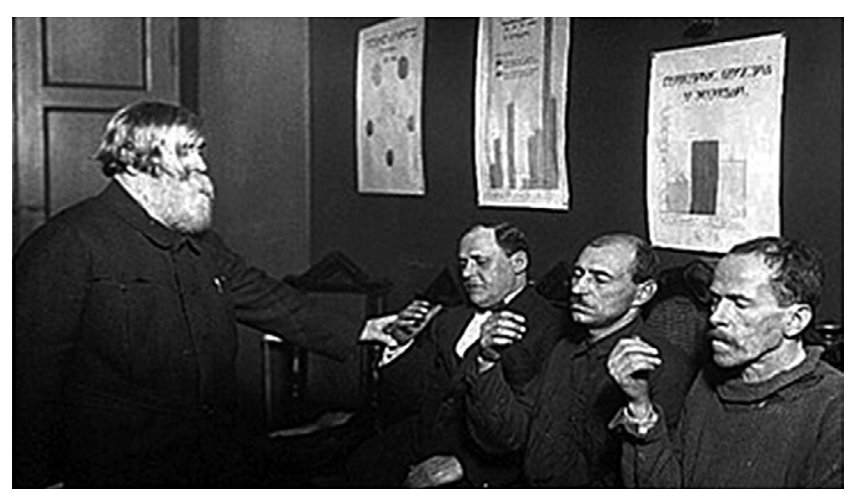

Access: http://www.ovguide.com/vladimir-bekhterev-9202a8c0400064 1 f8000000000435351

Figure 2. Bekhterev during session of mass hypnosis. Image obtained from a movie.

\section{BEKHTEREV'S ACCOMPLISHMENTS AND LEGACY}

The Doctor thesis granted him the Private-Docent title, and in 1884 he obtained a full-time position in the Clinic of Mental Disorders ${ }^{1}$. He submitted 58 works on nervous and mental diseases to a competition board, and as a winner he was sent to Europe in order to expand his competences. In Germany he attended to lectures by Westphal, Ludwig, du Bois-Reymond, and later he worked with Flechsig and Wundt; in Paris he acquainted himself with the work of Charcot, and finally he visited Meynert, in Vienna ${ }^{1,2,5,6}$. While travelling he accepted an invitation to occupy the Chair of Psychiatry in the Kazan University, taking the position on his return ${ }^{1,4}$. There, he reorganized the Chair, and founded a Psychophysiological Laboratory, the first in Russia, in 1885, with special equipments and trained collaborators to study morphology and physiology of the nervous system ${ }^{6}$. As one of the results of his research, he proposed a division of the brain in zones, each with a specific function, being one of the first to reveal the role of the hippocampus in memory function ${ }^{1,2,3}$. Further, aware that nervous and mental disorders usually occur in conjunction, he believed that there was no definite distinction between them, a trend towards neuropsychiatry ${ }^{4,5}$.

Some years later, in 1893, he returned to the Military Medical Academy to head the Chair of the Clinic of Mental Diseases ${ }^{1}$. Interested in the study of psychology, with his idea "that the man should be regarded as 'a single whole' or 'a biosocial entity' whose understanding requires the study of human consciousness and psychology", he suggested to establish the Psychoneurological Institute, founded in 1907, and later named after him. The following four years he spent organizing the Bekhterev Psychoneurological Institute, and in 1911 its exclusive building was erected ${ }^{1}$. There he installed a special unit for surgical treatment of nervous and mental diseases, the $1^{\text {st }}$ in Russia. He performed psychophysiological experiments, and studied "reflexology", a term he coined, and "objective psychology", a novel concept he introduced. Bekhterev and Pavlov, independently, studied the relation between the organism and the environment - Bekhterev described the fundamental phenomenon of this field as "association reflex", while Pavlov, as "conditioned reflex" ${ }^{2,3,6}$. After longstanding friendship arose a rivalry between them, with reciprocal criticisms. Bekhterev viewed Pavlov's use of the "salivatory method" as a flaw, as it could not be easily elicited in men, while Bekhterev's method was grounded on mild electrical stimulation to examine motor reflexes, allowing to demonstrate the existence of this response in men $^{7}$. Both were precursors to American Behaviorism, established by Watson, who followed, however, Pavlov's teachings. Despite their disputes, six years after Bekhterev's death Pavlov admitted to a friend that "...only now I feel how much I miss the arguments with Bekhterev"2,5,6,8. Concerning "objective psychology", Bekhterev created and developed the main concepts of this new field of psychological science. He claimed that all mental processes were accompanied by reflex movements and vegetative reactions, which could be observed and registered ${ }^{4}$. Expanding further the psychology field, Bekhterev was one of the first Russian scientists who focused the phenomenon of "suggestion", establishing its theoretical foundations?.

His inexhaustible intellect, generating a wide range of ideas and concepts, and his infatigable capacity to work, were expressed in more than 800 papers, 10 books and hundreds of conferences ${ }^{1,2,4,8}$. He founded the "Bulletin of Neurology" (1892), the first Russian newspaper on Neurology, standing as its editor in the following years, and also founded or gave direct assistance, until 1925, to nine other journals related to all fields of his interests ${ }^{1,4,8}$. His contributions to neurology (enhancing the knowledge on how the brain works), and psychology (establishing the foundation for the future of psychology) were impressive. His name is related to diseases, signs, symptoms, reflexes, methods, and tests, many named after him ${ }^{1,2,3,10}$ (Table). 
Table. Vladimir Bekhterev's legacy - main eponyms s $^{3,7,10}$.

\begin{tabular}{|c|c|}
\hline EPONYMS & DESCRIPTION \\
\hline Bekhterev band & $\begin{array}{l}\text { Cerebral cortex band between outer Baillarger band and tangential fibers of molecular layer; also known as } \\
\text { Kaes-Bekhterev band }\end{array}$ \\
\hline Bekhterev nucleus & Superior vestibular nucleus \\
\hline Bekhterev phenomenon & $\begin{array}{l}\text { Multiple mechanisms, vestibulo-ocular and vestibulo-spinal reactions, following the bilateral loss of } \\
\text { vestibular function, act in the compensation of the vestibular system }\end{array}$ \\
\hline Bekhterev nistagmus & $\begin{array}{l}\text { Compensatory nystagmus or 'recovery nystagmus' - reversal of post-unilateral labyrinthectomy spontaneous } \\
\text { nystagmus following subsequent contralateral labyrinthectomy }\end{array}$ \\
\hline $\begin{array}{l}\text { Bekhterev-Brissaud } \\
\text { syndrome }\end{array}$ & $\begin{array}{l}\text { Spasmodic crying: in patients with hemiplegia; probably the first abnormal emotional contribution due to the } \\
\text { involvement of the brainstem, as suggested by Brissaud }\end{array}$ \\
\hline Bekhterev signs & $\begin{array}{l}\text { [1] Paradoxical dilatation of the pupil to light stimulation in syphilis } \\
\text { [2] Mendel-Bekhterev (1900/1901): in pyramidal tract dysfunction, the foot dorsum percussion promotes } \\
\text { plantar flexion of the toes } \\
\text { [3] In pyramidal hemiplegia, when the foot is released after being passively flexed plantarwards occurs } \\
\text { dorsiflexion of the foot, and knee and hip flexion } \\
\text { [4] Hypogastric reflex observed in tertiary neurosyphilis: normal contraction of the lower abdominal wall } \\
\text { muscles when the peroneal nerve is compressed } \\
\text { [5] Absence of pain when the peroneal nerve is compressed, in tertiary neurosyphilis } \\
\text { [6] Nasal Reflex: contraction of the ipsilateral facial muscles to nasal stimulation (tickle) - normal } \\
\text { phenomenon } \\
\text { [7] Severe sciatica: the healthy leg can't extend more than the compromised one } \\
\text { [8] Arm dropping test: in pyramidal tract lesion, when the previously sustained arm is suddenly released, an } \\
\text { interval of seconds occurs before it drops } \\
\text { [9] Jacobsohn-Bekhterev: in pyramidal disorder, a distalwards pressure on the forearm radial edge causes } \\
\text { extension and abduction of the thumb } \\
\text { [10] Bekhterev's reflex of eye - contraction of the muscle orbicularis oculi on in the area of the forehead- } \\
\text { temple or on the cheekbone }\end{array}$ \\
\hline Bekhterev disease & $\begin{array}{l}\text { "Numbness of the spine" } \\
\text { Rheumatology - Ankylosing spondylitis } \\
\text { (or Bekhterev-Marie-Strümpell disease) }\end{array}$ \\
\hline
\end{tabular}

\section{BEKHTEREV'S DEATH AND UNFOLDINGS}

In December 1927, at the summit of his prestige, during the First Congress of Neurologists and Psychiatrists of Soviet Russia, in Moscow, came his termination, in a quick way and suspicious circumstances ${ }^{1,2,5,6}$ (Box).
In conclusion, Bekhterev was an intellectually gifted person, originating a wide range of contributions with ample repercussion in the dominion of the neurosciences. Revered as an encyclopedic scientist, received the admirative quotation attributed to the eminent German anatomist Friedrich Kopsch" 2,3,5: "Only two know the mystery of brain structure and organization: God and Bekhterev".

Box. Circumstances of Bekhterev's death ${ }^{1,2,5,6}$.

The chronicle about Bekhterev's death, despite some narrative variations, recounted that the neurologist, before the beginning of the Congress, by official request of the Kremlin Medical Department, examined Joseph Stalin.

On returning to the Congress, he explained his delay for an important meeting as follows: "I examined a paranoid with the dry hand". It appears that this comment, reaching Stalin (that had a left hand deformity), distressed him very much, as he could not admit rumors about his mental state. According authors, during the Congress break, Bekhterev was invited for a snack at the buffet. Later, in his apartment, he felt very sick, and next morning he was seen by a physician who diagnosed 'gastric irritation'. His condition quickly worsened leading to his death from "respiratory failure". Next morning, by authorization of the Health Minister, his brain was removed and, despite the opposition of his relatives, his body was sent for cremation. Regardless the absence of corroborative evidence material, authors speculated that he has possibly been poisoned.

A formal funeral was held on the next day. Apparently, shortly after the burial, the grave disappeared, and effort has been made to erase his scientific legacy and fame. The Bekhterev Institute was closed, his books and articles were forbidden to be republished, and his name was not mentioned in the country until the end of Stalin's era, in 1953.

Later, Bekhterev was rehabilitated and recognized as one of the outstanding Russian neurologist. His grave was rediscovered and restored in 1970 and his work slowly reappeared. 


\section{References}

1. Akimenko MA. Vladimir Mikhailovich Bekhterev. J Hist Neurosci. 2007;16(1-2):100-9. doi:10.1080/09647040600550541

2. Lerner V., Margolin J., Witztum E. Vladimir Bekhterev: his life, his work and the mystery of his death. Hist Pschyatry. 2005;16(2):217-27. doi:10.1177/0957154X05049611

3. Amirov NKH, Bogdanov El, Guryleva ME, Zefirov AL, Ismagliov MF, Mukhamedzyanov RZ et al. The history of Kazan neurological school. J Hist Neurosci. 2007;16(1-2):110-22. doi:10.1080/09647040600659086

4. Kizilova A. Vladimir Bekhterev. Russia InfoCenter. 2015 [Last access: January 20, 2015]. Available from: http://russia- ic.com/people/general/b/348

5. Kesselring J. Vladimir Mikhailovic Bekhterev (1857-1927): strange circumstances surrounding the death of the great russian neurologist. Eur Neurol, 2011;66(1):14-7. doi:10.1159/000328779

6. Sirotkina IVM. Bekhterev and the beginnings of experimental psychology in Russia. Rev Hist Psicol. 2007;28(2/3):315-20.

7. World Heritage Encyclopedia. Vladimir Bekhterev. World eBook Library; [Last access: January 22, 2015] Available from: http://ebooklibrary.org/articles/Vladimir_Bekhterev

8. Razran G. Bekhterev, Vladimir M. In: Sills DL. International Encyclopedia of the Social Sciences. New York: Mcmillan, 1968.

9. Fedotova O. The genesis of the theoretical foundations of "Psychology of suggestion" of V. M. Bekhterev. Proc Soc Behav Sci. 2014;146:147-53. doi:10.1016/j.sbspro.2014.08.102

10. Dorland WAN. The American illustrated medical dictionary. 20th ed. USA Saunders; 1944. p.212. 